\title{
Microtubule stabilising agents and ionising radiation: Multiple exploitable mechanisms for combined treatment
}

Rohrer Bley, Carla ; Furmanova, Polina ; Orlowski, Katrin ; Grosse, Nicole ; Broggini-Tenzer, Angela ; McSheehy, Paul M J ; Pruschy, Martin

\begin{abstract}
Combined radiochemotherapy treatment modalities are in use for many indications and there-fore of high interest. Even though a combined modality in clinical use is often driven by prag-matic aspects, mechanistic preclinical-based concepts of interaction are of importance in order to translate and implement an optimal combination and scheduling of two modalities into the clinics. The use of microtubule stabilizing agents is a promising strategy for anti-cancer therapy as a part of combined treatment modality with ionizing radiation. Traditionally, microtubule targeting agents are classified as cytotoxic chemotherapeutics and are mostly used in a maxi-mally tolerated dose regimen. Apart from direct cytotoxicity and similar to mechanisms of mo-lecular targeting agents, microtubule stabilizing agents interfere with multiple cellular process-es, which can be exploited as part of combined treatment modalities. Recent preclinical investi-gations on the combination of ionizing radiation and microtubule stabilizing agents reveal new mechanistic interactions on the cellular and tumor level and elucidate the supra-additive tumor response observed particularly in vivo. The major focus on the mechanism of interaction was primarily based on radiosensitization due to cell cycle arrest in the most radiosensitive G2/Mphase of the cell cycle. However, other mechanisms of interaction such as reoxygenation and direct as well as indirect endothelial damage have also been identified. In this review we sum-marize and allocate additive and synergistic effects induced by the combined treatment of clini-cally relevant microtubule stabilizing agents and ionizing radiation along a described radiobio-logical framework encompassing distinct mechanisms relevant for exploiting the combination of drugs and ionizing radiation.
\end{abstract}

DOI: https://doi.org/10.1016/j.ejca.2012.05.008

Posted at the Zurich Open Repository and Archive, University of Zurich ZORA URL: https://doi.org/10.5167/uzh-68375

Journal Article

Originally published at:

Rohrer Bley, Carla; Furmanova, Polina; Orlowski, Katrin; Grosse, Nicole; Broggini-Tenzer, Angela; McSheehy, Paul M J; Pruschy, Martin (2013). Microtubule stabilising agents and ionising radiation: Multiple exploitable mechanisms for combined treatment. European Journal of Cancer, 49(1):245-253.

DOI: https://doi.org/10.1016/j.ejca.2012.05.008 
Microtubule Stabilizing Agents and Ionizing Radiation: Multiple Exploitable Mechanisms for Combined Treatment

Carla Rohrer Bley ${ }^{\mathrm{a}, \mathrm{b} ;}$, Polina Furmanova ${ }^{\mathrm{a}}$, Katrin Orlowski ${ }^{\mathrm{a}}$, Nicole Grosse ${ }^{\mathrm{a}}$, Angela BrogginiTenzer $^{\mathrm{a}}$, Paul MJ. McSheehy ${ }^{\mathrm{c}}$, Martin Pruschy ${ }^{\mathrm{a}}$

${ }^{a}$ Department of Radiation Oncology, University Hospital Zurich, Zurich, Switzerland

${ }^{b}$ Division of Radiation Oncology, Vetsuisse Faculty, University of Zurich, Zurich, Switzerland

${ }^{c}$ Novartis Institutes for BioMedical Research, Novartis Pharma AG, Basel, Switzerland

*Corresponding author: Carla Rohrer Bley

Address:

Division of Radiation Oncology

Vetsuisse Faculty, University of Zurich

Winterthurerstrasse 260

CH-8057 Zurich, Switzerland

Tel: +41446358487

fax: +41 446358940

crohrer@vetclinics.uzh.ch

Short title: Microtubule Stabilizing Agents and Ionizing Radiation 


\begin{abstract}
Combined radiochemotherapy treatment modalities are in use for many indications and therefore of high interest. Even though a combined modality in clinical use is often driven by pragmatic aspects, mechanistic preclinical-based concepts of interaction are of importance in order to translate and implement an optimal combination and scheduling of two modalities into the clinics. The use of microtubule stabilizing agents is a promising strategy for anti-cancer therapy as a part of combined treatment modality with ionizing radiation. Traditionally, microtubule targeting agents are classified as cytotoxic chemotherapeutics and are mostly used in a maximally tolerated dose regimen. Apart from direct cytotoxicity and similar to mechanisms of molecular targeting agents, microtubule stabilizing agents interfere with multiple cellular processes, which can be exploited as part of combined treatment modalities. Recent preclinical investigations on the combination of ionizing radiation and microtubule stabilizing agents reveal new mechanistic interactions on the cellular and tumor level and elucidate the supra-additive tumor response observed particularly in vivo. The major focus on the mechanism of interaction was primarily based on radiosensitization due to cell cycle arrest in the most radiosensitive G2/Mphase of the cell cycle. However, other mechanisms of interaction such as reoxygenation and direct as well as indirect endothelial damage have also been identified. In this review we summarize and allocate additive and synergistic effects induced by the combined treatment of clinically relevant microtubule stabilizing agents and ionizing radiation along a described radiobiological framework encompassing distinct mechanisms relevant for exploiting the combination of drugs and ionizing radiation.
\end{abstract}

Keywords: Ionizing Radiation, Microtubule Stabilizing Agents, Radiochemotherapy, Epothilones, Taxanes 


\section{Introduction: Microtubule Stabilizing Agents}

Microtubule targeting agents belong to the most important classes of anti-cancer agents and are subdivided in two groups, according to their mode of action. While microtubule destabilizers prevent the assembly of tubulin heterodimers, microtubule stabilizing agents (MSA) prevent the shortening of microtubules resulting in the accumulation of polymerized microtubule bundles and the interference of the mitotic spindle function.(1-4) Experimental evidence concerning the kinetics and mechanism of tubulin-binding as well as the ability to actively promote microtubule function by paclitaxel mimetics has been recently provided using biochemical and NMR techniques.(5) Eventually both classes of microtubule targeting agents alter spindle-microtubule dynamics, which results in a transient or permanent M-phase arrest and the induction of apoptotic cell death or mitotic catastrophe (Figure 1).(6) In this review we will specifically focus on the mode of interaction between MSA and ionizing radiation as part of a combined treatment modality.

Taxanes and epothilones are the clinically most relevant microtubule stabilizing agents. The taxanes (paclitaxel and docetaxel) have been approved for a broad range of indications, including advanced breast cancer after failure of combination chemotherapy or at early relapse,(7) high grade ovarian cancer in combination with platinum compounds, and primary treatment of non-small cell lung cancer in combination with cisplatin.(8) Furthermore paclitaxel is used in an "off-label manner" for other tumor types, such as cancer of unknown origin, bladder, esophagus, gastric, head and neck, and cervical cancers (reviewed in (9)). Paclitaxel has also been evaluated clinically for its radiosensitizing properties for various tumors(10-14) and drug plasma concentrations in patients. Low concentrations with prolonged exposure during long parts of the course of radiation therapy have been found feasible and tolerated in patients.(12-18) Docetaxel is used as first-line chemotherapy for locally advanced or metastatic breast cancer,(19) nonresectable, advanced or metastatic non-small cell lung cancer after failure of cisplatin-based therapy, hormone-refractory metastatic prostate cancer in combination with prednisone,(20) gastric adenocarcinoma in combination with cisplatin and 5-fluorouracil,(21) and inoperable 
advanced squamous cell cancer of the head and neck in combination with cisplatin and 5fluorouracil. Both of the approved taxane derivates are hydrophobic and require organic solvents for administration (cremophor EL / ethanol, polysorbate / ethanol), which by themselves can cause unwanted side effects.(22) The epothilones are nontaxoid macrolide MSA of bacterial origin, which share the same binding site on beta-tubulin (in close proximity to residue Thr274) with taxanes,(23) albeit with different affinities.(1,24-26) Clinically different epothilone derivatives are currently in various stages of development as antitumor compounds. Several properties like increased water solubility, low susceptibility to common mechanisms of resistance and the more tolerable toxicity profile, favor their development. Ixabepilone (Ixempra®) is the first approved compound in this class and indicated as monotherapy or in combination with capecitabine for the treatment of patients with metastatic breast cancer. Apart from a manageable safety profile, ixabepilone demonstrates activity after failure and resistance towards anthracycline and taxane standard therapy.(27) Epothilone B (patupilone) was tested as a phase III monotherapy agent against ovarian cancer and other epothilones are undergoing a wide spectrum of single and combined treatment modality in phase II studies (e.g. for recurrent glioblastoma, CNS metastases from breast cancer, prostate, cervical, renal cell, gastric and lung tumor, as well as non-Hodgkin's Lymphoma (www.cancer.gov).(15, 28-31)

Both, taxanes and epothilones, have been extensively tested at the preclinical level in combination with ionizing radiation, demonstrating a strong supra-additive treatment response. Here, we will outline classic rationales for the combined treatment modality of ionizing radiation with microtubule stabilizing agents and discuss novel mechanistic preclinical-based concepts of interaction between these two modalities.

\section{Rationale for the Combined Use of Irradiation and Cytotoxic Agents}

The rationale for a combined treatment with ionizing radiation (IR) and chemotherapy is to increase survival by improving locoregional tumor control and decrease the probability of distant 
disease, with concurrent organ and function preservation. $(32,33)$ Recently, a new framework encompassing five distinct mechanisms relevant for exploiting the combination of drugs and ionizing radiation has been proposed.(34) While for some of the mechanisms direct drugradiation interactions at the tumor-cellular level is not required (e.g. in spatial cooperation, normal tissue protection), other mechanisms are fundamentally based on their mutual interaction (e.g. cytotoxic enhancement, biological cooperation, temporal modulation). With regard to microtubule stabilizing agents, IR-MSA interactions can be allocated to several of these mechanisms. Interestingly these mechanisms even complement each other on several levels thereby further enhancing the potency of this promising combined treatment modality.

The main rationale to exploit spatial cooperation, combining a drug with efficacy against systemic disease with radiotherapy against locoregional disease, is to achieve local and systemic control by full doses of both treatment modalities, often applied in sequence.(20) For the mechanisms involving a direct drug-radiation interaction at the cellular level (cytotoxic enhancement, biological cooperation and temporal modulation), the strategies aim mainly at enhancing cell killing, interfering with repair mechanisms, targeting distinct cell populations (e.g. hypoxic cells) and microenvironmental structures within the tumor.

\section{Interactions between Ionizing Radiation and MSA (Figure 2)}

Cell cycle specific enhancement (cytotoxic enhancement). MSAs induce mitotic arrest in most tumor cells. Depending on the dose applied and/or the genetic background and inherent cellular sensitivity of the tumor cells, MSA-induced mitotic arrest will lead to transient cell cycle arrest or apoptosis. Therefore only a poor correlation exists between MSA-induced mitotic arrest and tumor control, as mitotically arrested cells in some tumors are capable of continued survival (35, 36). In paclitaxel- and docetaxel-resistant tumors, the radioenhancing mechanism is primarily based on the transient accumulation of cells in this cell cycle phase. $(36,37)$ 
The cell cycle phases of late G2 and mitosis are most sensitive to ionizing radiation. $(38,39)$ Ionizing radiation produces different types and quantities of chromosomal aberrations at various stages of the cell cycle. The frequency of IR-induced chromosomal aberrations is higher for cells in G2- and M-phase than for cells irradiated in the G1- and S-phase of the cell cycle.(40) In addition, cells in late G2/M-phase already passed the G2-checkpoint to repair their DNA damage, and thus the frequency of residual, detrimental chromosomal aberrations in cells entering mitosis is also increased. As mitotic cells with double strand breaks will lose genetic material following cell division, irradiation of MSA-treated, transiently arrested late G2-/M-phasecells will result in genomic instability and eventually mitotic catastrophe. $(35,41-45)$

This implies that the therapeutic efficacy of the combined treatment modality strongly depends on the innate cellular drug sensitivity and in particular on the combination scheduling. Indeed, effects ranging from supra-additive interactions (Figure 3), to additive, and even sub-additive effects are documented.(43, 46-50) The radiosensitizing effect of MSA is most prominent between 8-12 hours after start of drug exposure at the time of accumulation of cells in G2/M-phase (Figure 4).(42, 43, 49, 50) In contrary, the cytotoxic M-phase-related potency of paclitaxel added after irradiation was lost and did not increase IR-induced cell death due to the strong IRinduced G1- and G2- cell cycle arrest and subsequent sublethal damage repair. $(49,51)$ In vivo, multiple doses of taxanes given during the course of fractionated irradiation maximized the exposure for cells to ionizing radiation even in drug resistant tumors.(52) However, with intermittent multiple high doses of taxanes, the therapeutic gain was in part limited by side effects in acutely responding tissues such as jejunal mucosa, skin and connective tissues as observed in murine tumor models.(52-54)

Moderate concentrations of MSA, which are sufficient to induce a G2-M cell cycle arrest are optimal for radioenhancement.(43, 47-50) Interestingly, low dose MSA-treatment may also induce an additional G2/M-phase independent mode of radiosensitization. Low doses of patupilone induced a transient accumulation of cells in S phase, but only on combined treatment with ionizing radiation.(55) Combined treatment did not result in the accumulation of cells in the 
radiosensitive G2/M-phase and radiosensitization was rather due to an S-phase-related process. A similar effect has also been described for synchronized HeLa cells, in which docetaxel resulted in a S-phase specific (and hence radioresistant) cell killing.(56, 57)

Furthermore there seems to be a tendency toward a concentration-dependent increase in DNA double strand breaks after combined treatment, suggesting a reduction of DSB repair capacity as an additional mechanism of sensitization.(46)

Reoxygenation theory (biological cooperation, temporal modulation). The enhanced radiation response of combined treatment with microtubule stabilizing agents and ionizing radiation has also been attributed to "tumor cell reoxygenation". Massive cell loss due to MSA-induced apoptosis or necrosis might lead to a shortening of the tumor cell-vascular distance and a decrease of the intratumoral fluid pressure (IFP) with a subsequently increased blood delivery to hypoxic tumor regions as well as a decreased overall oxygen consumption rate. Eventually this results in increased tumor oxygenation, and subsequently increased radiation sensitivity (Figure 4).(35, $37,52,54,58,59)$ For example, paclitaxel in combination with ionizing radiation significantly reduced tumor hypoxia in MCA-4 xenograft tumors, especially in a drug-radiation interval of 3 days.(59) Due to the high concentration of the administered drug, this effect was mostly attributed to extensive cytotoxicity caused by paclitaxel.

Endothelial theory (biological cooperation, temporal modulation). As the radiosensitivity of the tumor vascular network codetermines the tumor response to IR, enhanced tumor radiosensitivity can be attributed to the effect of microtubule agents on the tumor endothelial system.(60) Microtubule stabilizing agents have anti-angiogenic properties at high and at low, non-tumor cytotoxic doses.(61) These properties are on one hand based on direct anti-endothelial cell activity, but also on the indirect tumor-cell mediated anti-angiogenic effect, by inhibition and subsequent down-regulation of proteins and genes involved in angiogenesis and hypoxic adaptation.(62, 63) 
High doses of microtubule stabilizing agents act in a cytotoxic manner via mitotic block and activation of the mitochondrial apoptotic pathway, while on the other hand, low doses decelerate overall cell cycle progression and inhibit migration and proliferation, $(64,65)$ which results in reduced capillary-like tube formation. $(61,66)$ Similar to the radiosensitizing effect on the tumor cell level, prolonged metaphase-to-anaphase transition in endothelial cells can also provoke an increase of the radiation response on the tumor vasculature level by temporal modulation in the classic radiobiological framework of cell cycle redistribution (see above).(34) In addition to the anti-angiogenic effects, MSA such as epothilone B also exert vascular disruptive effects. Drug administration led to a rapid destruction of blood vessels (observable at day two) associated with a decrease in tumor IFP.(67) This direct destruction of blood vessels and decrease of IFP might also lead to a subsequent reorganization of the vasculature, thereby temporarily decreasing the hostility of tumor microenvironment by also changing oxygenation and pH-status of the tumor. $(67,68)$ Enhanced tumor oxygenation could also be attributed to the proposed concept of tumor vasculature normalization, caused by a transient decrease of VEGF signaling and thereby reduction of vessel abnormalities such as tortuosity and leakage of the impaired tumor vasculature. Addition of radiation therapy during this "window of normalization" would in principle enhance radiation response. $(68,69)$

However, reduction of tumor hypoxia on MSA-treatment is not a prerequisite for a supraadditive anti-tumor effect when combined with ionizing radiation. Early results indicated that paclitaxel suppresses the expression of VEGF in murine breast cancer cells in vivo and in vitro.(70) Our own experiments performed with patupilone in a genetically defined MSAsensitive and MSA-resistant tumor model revealed that the anti-angiogenic and radiosensitizing effect on the level of the tumor vasculature of MSA is strongly promoted in an indirect tumorcell mediated way. A significant reduction in microvessel density and initial increase of tumor hypoxia on treatment with epothilone B (patupilone) alone was only detected in tumors derived from the MSA-sensitive A549 wild-type cells but not in the MSA-resistant cell line. These results indicate that the anti-angiogenic effect of patupilone in vivo is indirectly induced by inter- 
ference at the level of the tumor cellular stress response. $(62,71)$ MSA interfere with the expression and transcriptional activity of the hypoxia-inducible factor $1 \alpha$ (HIF-1 $\alpha)$ and subsequent reduction of the downstream pro-angiogenic HIF-transcriptome, including VEGF and other genes involved in angiogenesis, endothelial cell survival and hypoxic adaptation.(62, 63, 71) Vascular disruption as well as a decrease of the radioprotective effect of endothelial cells by VEGF and other survival factors will thereby enhance the radiation response, which is attributed to biological cooperation. $(34,60,72)$

Antimetastatic properties of MSAs (spatial cooperation). There is currently an ongoing discussion on the impact of ionizing radiation on tumor cell dissemination. Enhanced cell invasion and metastatic spread was observed in selected preclinical experiments in response to irradiation.(73-77) This effect is most probably due to IR-induced expression and secretion of matrix metalloproteinases (MMPs) required for cell invasion.(78-81) Interestingly the secretion of MMPs and related tissue inhibitors of metalloproteinases are also regulated by MSAs, as they are at least partially dependent on the dynamic functional MT system.(82, 83) At low doses, paclitaxel impairs the secretion of MMP-2 and MMP-9 by human melanoma and prostate cancer cells, thereby inhibiting cell invasion $(84,85)$ and this may be relevant mechanistically for the promising anti-metastatic effect of MSA. Furthermore, taxanes and epothilones can reduce migration of non-neoplastic smooth muscle and endothelial cells,(86-88) as well as neoplastic tumor cells (e.g. ovarian and colon carcinoma).(89, 90) The anti-metastatic properties of paclitaxel and epothilones were also demonstrated in tumor-bearing mice (for lung, prostate and breast tumors).(91-94)

Our own studies are currently investigating the combined treatment modality of epothilones and IR on MMP function. Interestingly, epothilones specifically counteract IR-induced MMP activity and IR-induced cell invasion of human fibrosarcoma and glioma cell lines.(95) This might represent an additional cause for the supra-additive tumor growth delay observed on combined treatment in preclinical in vivo experiments and is an interesting rational for a combined treat- 
ment modality in the clinical setting.

The combined treatment modality of ionizing radiation with microtubule stabilizing agents fulfill the classic rationales of cell cycle specific enhancement, biological cooperation, temporal modulation and, in part, spatial cooperation. By causing cell cycle arrest in the most radiosensitive phase of the cell cycle, reducing the hypoxic fraction within the cellular population and thereby redistributing and reoxygenating the remaining tumor cells, and by interference with angiogenic signaling and endothelial cells, the interaction between microtubule stabilizing agents and ionizing radiation has a promising potential to increase the potency of this treatment combination. It is not only the additive effect of each of these mechanisms, which contribute to radiosensitization by MSAs, interestingly these mechanisms even complement each other on several levels thereby further enhancing the potency of this promising combined treatment modality.

\section{Conflict of interest statement:}

No potential conflicts of interest were disclosed.

Grant Support: Swiss Cancer League, Vontobel-Stiftung, Swiss National Science Foundation 


\section{Figure legends:}

Fig. 1.

A: Chemical structure: The MSA compounds are of complex structure and high chemical diversity. The complex structure of these compounds explains the difficulty for chemical synthesis.

B: Binding site: Microtubules are dynamic structures of $\alpha$ - and $\beta$-tubulin molecules arranged in tubular form. The microtubule-stabilizing agents of the taxane and epothilone groups bind along the interior surface of the microtubules to the same or an overlapping taxoid-binding site on $\beta$ tubulin. Thereby microtubular polymerization is enhanced and microtubular dynamics reduced.

C: Microtubules interact with various intracellular organelles: In the mitotic spindle, proper alignment and separation of the chromosomes during cellular division is provided by the normal microtubular function. Furthermore cellular structure and motion as well as vesicular transport take place by and along tubular structures.
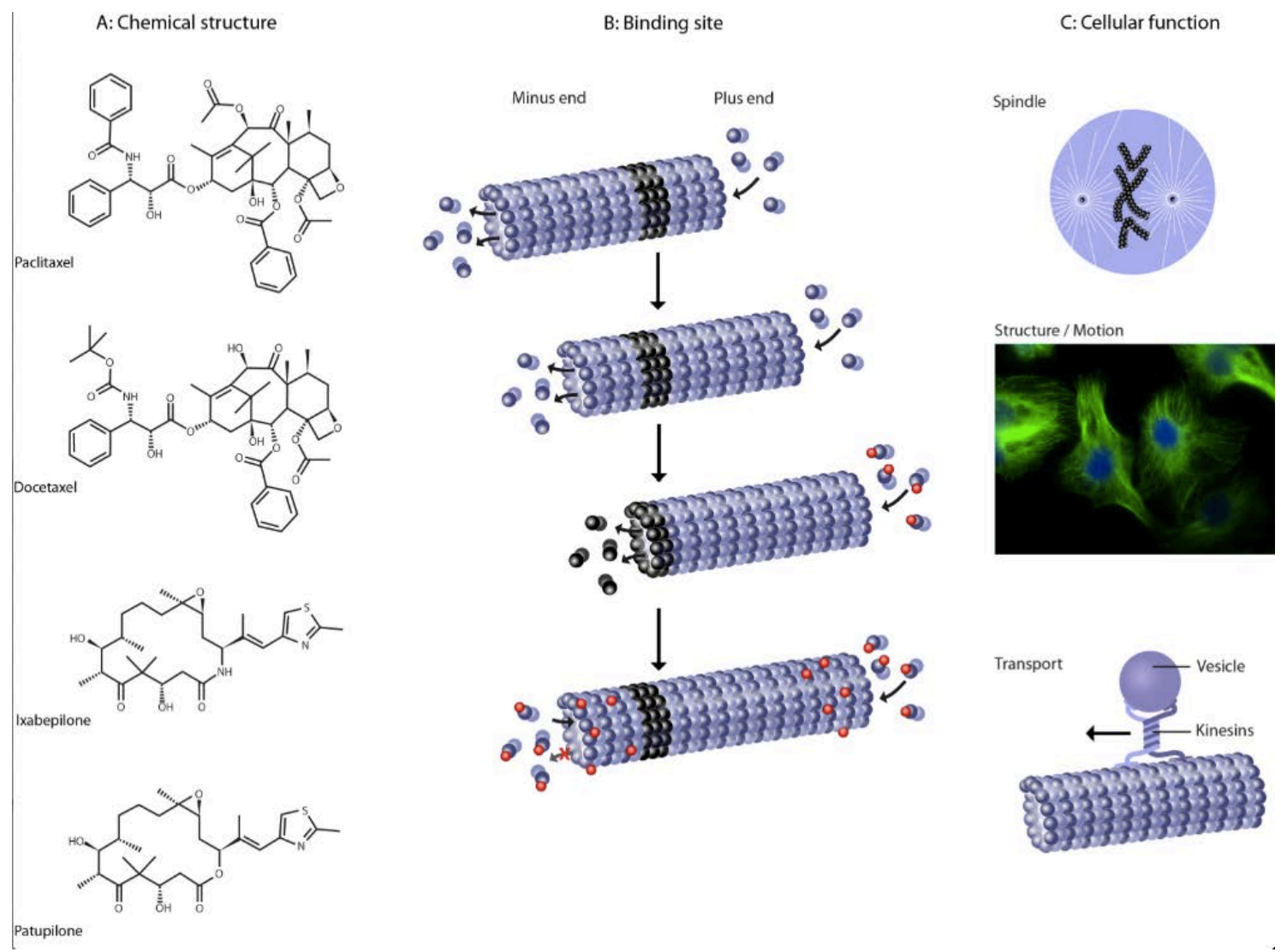
Fig. 2.

Multifaceted interaction of MSA and ionizing radiation on the tumor and endothelial cell level: 1. High doses of MSA and IR lead to reassortment of cells in the cell cycle, cell loss and subsequent tumor reoxygenation. Massive tumoral cell loss will directly decrease the metastatic potential. 2. MSAs counteract the pro-angiogenic IR-induced stress response. 3. MSAs counteract IR-induced secretion of survival and pro-metastatic factors thereby sensitizing the tumor to the combined treatment modality.

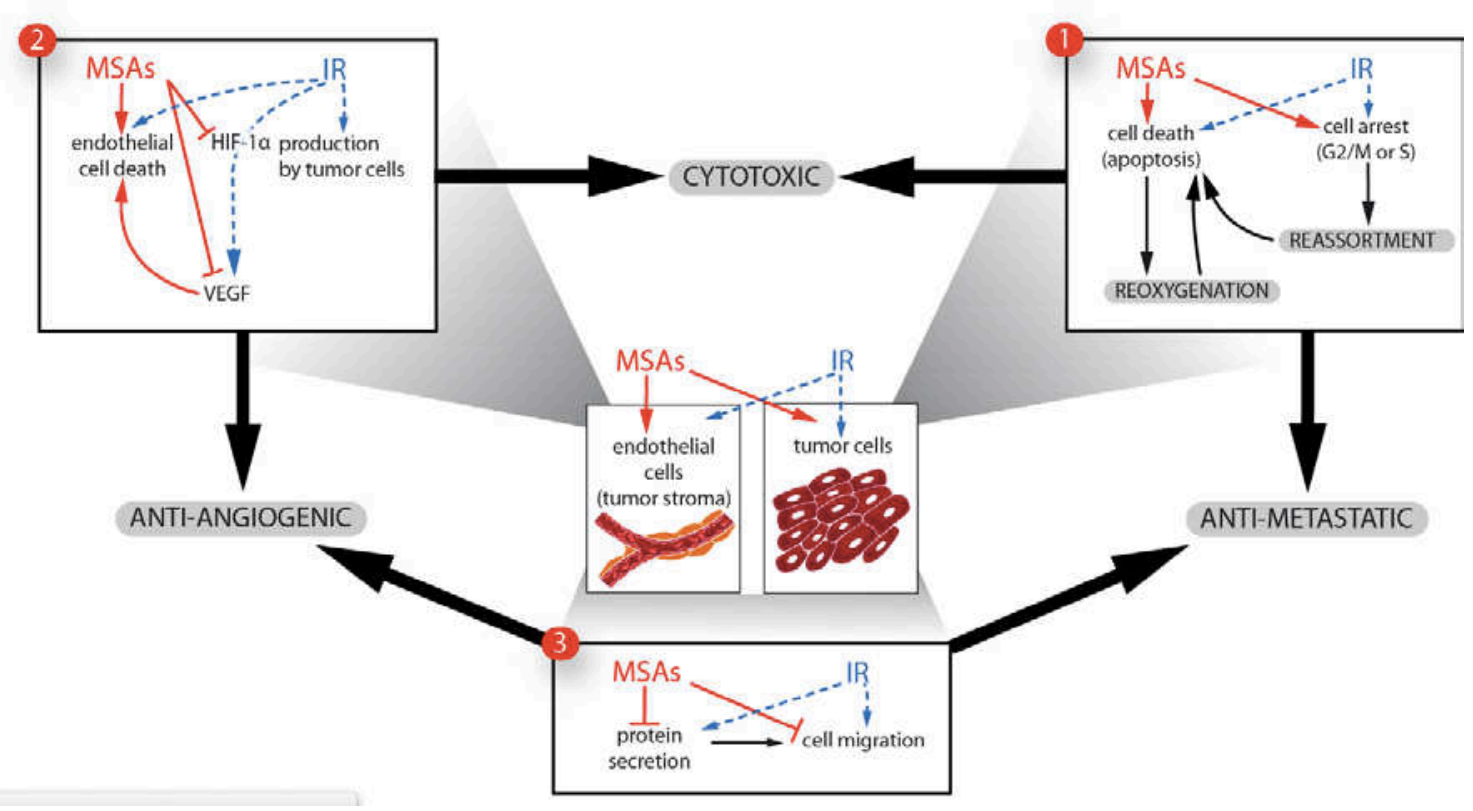

Fig. 3.

(Adapted from Hofstetter et al.,(55)). Effect of Patupilone and IR alone or in combination on the growth of SW480-derived xenografts in nude mice: Mice were treated with Patupilone (2 $\mathrm{mg} / \mathrm{kg}$, once) and IR ( $4 \times 3 \mathrm{~Gy}$, on 4 consecutive days), alone and in combination. Patupilone or the vehicle was administered 24 hours before the first fraction of IR. Combined treatment exerted a strong, supra-additive tumor growth control during treatment and the follow-up period. The human colon adenocarcinoma cell line SW480 is a p-glycoprotein (MDR1)-overexpressing tumor. Patupilone is a promising alternative in multidrug-resistant tumors for a combined treatment regimen using microtubule inhibitors and IR. 


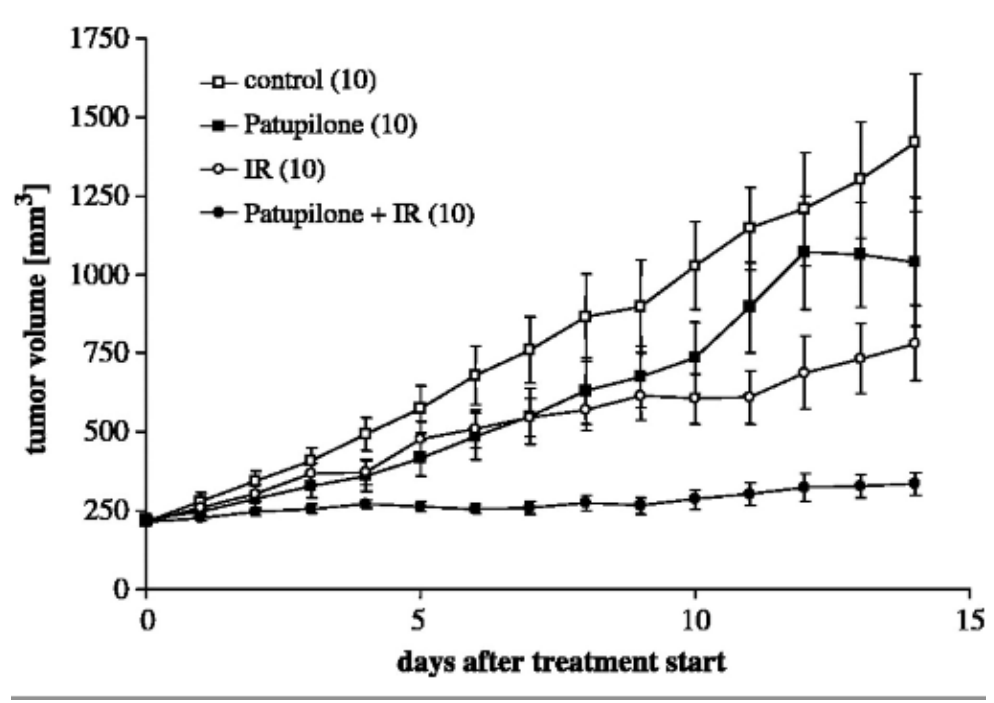

Fig. 4.

Dose dependent consequences of MSA via initial G2/M-phase block: cytostatic, low doses of MSA lead to cellular reassortment into the most radiosensitive phase of the cell cycle, while cytotoxic high doses of MSA radiosensitize the tumor by tumor reoxygenation.

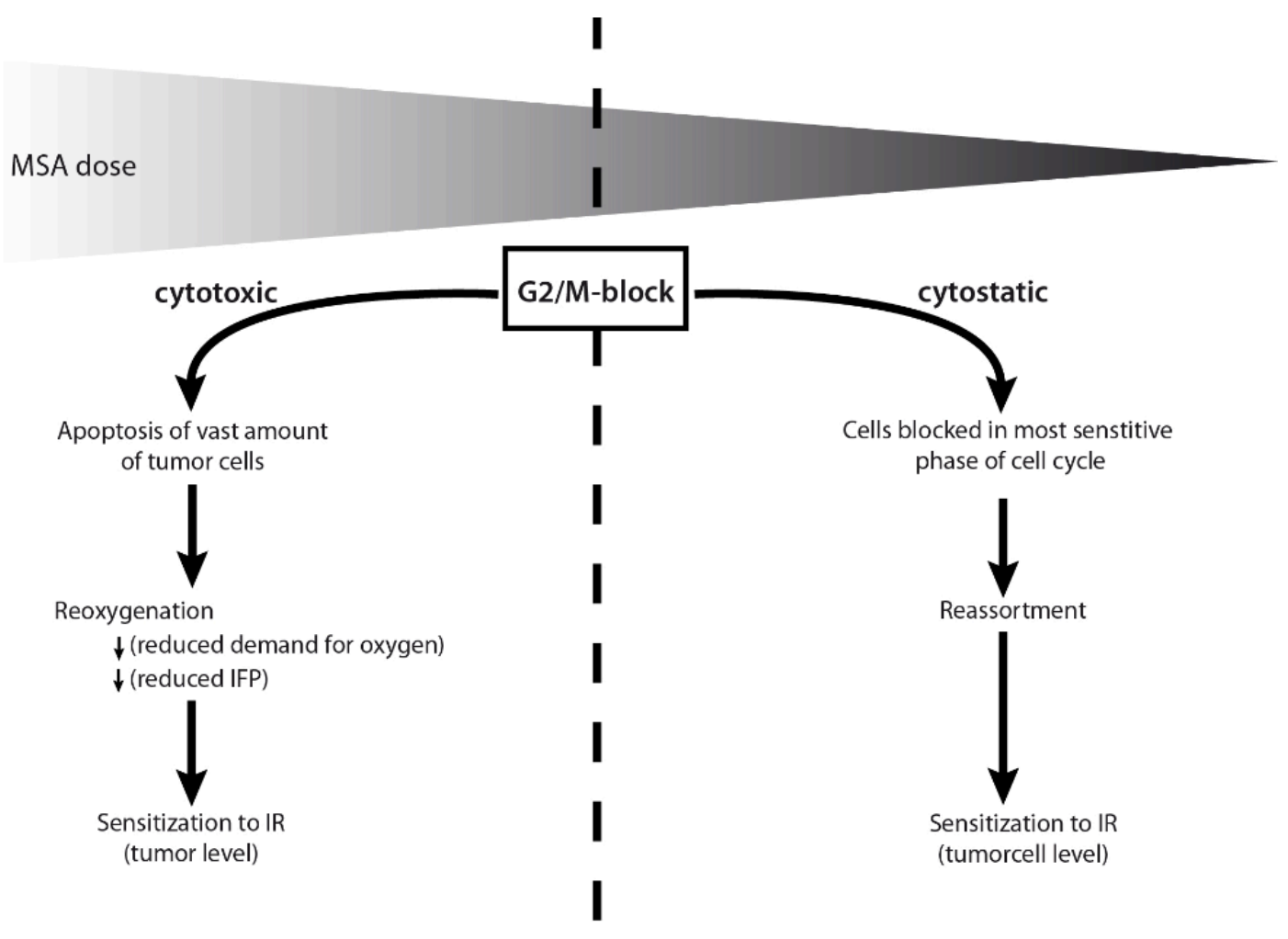




\section{References}

1. Bollag DM, McQueney PA, Zhu J, Hensens O, Koupal L, Liesch J, et al. Epothilones, a new class of microtubule-stabilizing agents with a taxol-like mechanism of action. Cancer Res 1995;55(11):2325-33.

2. Kowalski RJ, Giannakakou P, Hamel E. Activities of the microtubule-stabilizing agents epothilones A and B with purified tubulin and in cells resistant to paclitaxel (Taxol(R)). J Biol Chem 1997;272(4):2534-41.

3. Manfredi JJ, Parness J, Horwitz SB. Taxol binds to cellular microtubules. J Cell Biol 1982;94(3):688-96.

4. Schiff PB, Horwitz SB. Taxol stabilizes microtubules in mouse fibroblast cells. Proc Natl Acad Sci U S A 1980;77(3):1561-5.

5. Canales A, Rodriguez-Salarichs J, Trigili C, Nieto L, Coderch C, Andreu JM, et al. Insights into the interaction of discodermolide and docetaxel with tubulin. Mapping the binding sites of microtubule-stabilizing agents by using an integrated NMR and computational approach. ACS Chem Biol 2011;6(8):789-99.

6. Jordan MA, Wilson L. Microtubules as a target for anticancer drugs. Nat Rev Cancer 2004;4(4):253-65.

7. Sparano JA. Taxanes for breast cancer: an evidence-based review of randomized phase II and phase III trials. Clin Breast Cancer 2000;1(1):32-40; discussion 41-2.

8. Bonomi P, Kim K, Fairclough D, Cella D, Kugler J, Rowinsky E, et al. Comparison of survival and quality of life in advanced non-small-cell lung cancer patients treated with two dose levels of paclitaxel combined with cisplatin versus etoposide with cisplatin: results of an Eastern Cooperative Oncology Group trial. J Clin Oncol 2000;18(3):623-31.

9. Lee JJ, Harris LN. Antimicrotubule Agents. In: De Vita VT, Lawrence TS, Rosenberg SA, editors. Cancer, Priniples \& Practice of Oncology. 8th ed. Philadelphia: Lippincott Williams \& Wilkins; 2008. p. 447-456.

10. Klautke G, Foitzik T, Ludwig K, Ketterer P, Klar E, Fietkau R. Neoadjuvant radiochemotherapy in locally advanced gastric carcinoma. Strahlenther Onkol 2004;180(11):695-700.

11. Leibl BJ, Vitz S, Schafer W, Alfrink M, Gschwendtner A, Grabenbauer GG. Adenocarcinoma of the esophagogastric junction: neoadjuvant radiochemotherapy and radical surgery : early results and toxicity. Strahlenther Onkol 2011;187(4):231-7.

12. Liu L, Vapiwala N, Munoz LK, Winick NJ, Weitman S, Strauss LC, et al. A phase I study of cranial radiation therapy with concomitant continuous infusion paclitaxel in children with brain tumors. Med Pediatr Oncol 2001;37(4):390-2.

13. Rosenthal DI, Fuller CD, Machtay M, Algazy KM, Meyer DM, Kaiser LR, et al. Phase I study of Paclitaxel given by seven-week continuous infusion concurrent with radiation therapy for locally advanced non-small cell lung cancer. J Thorac Oncol 2006;1(1):38-45.

14. Rosenthal DI, Lee JH, Sinard R, Yardley DA, Machtay M, Rosen DM, et al. Phase I study of paclitaxel given by seven-week continuous infusion concurrent with radiation therapy for locally advanced squamous cell carcinoma of the head and neck. J Clin Oncol 2001;19(5):136373.

15. Fogh S, Machtay M, Werner-Wasik M, Curran WJ, Jr., Bonanni R, Axelrod R, et al. Phase I trial using patupilone (epothilone B) and concurrent radiotherapy for central nervous system malignancies. Int J Radiat Oncol Biol Phys;77(4):1009-16. 
16. Rosenthal DI, Close LG, Lucci JA, 3rd, Schold SC, Truelson J, Fathallah-Skaykh H, et al. Phase I studies of continuous-infusion paclitaxel given with standard aggressive radiation therapy for locally advanced solid tumors. Semin Oncol 1995;22(4 Suppl 9):13-7.

17. Wiernik PH, Schwartz EL, Einzig A, Strauman JJ, Lipton RB, Dutcher JP. Phase I trial of taxol given as a 24-hour infusion every 21 days: responses observed in metastatic melanoma. $\mathbf{J}$ Clin Oncol 1987;5(8):1232-9.

18. Wiernik PH, Schwartz EL, Strauman JJ, Dutcher JP, Lipton RB, Paietta E. Phase I clinical and pharmacokinetic study of taxol. Cancer Res 1987;47(9):2486-93.

19. Jones SE, Erban J, Overmoyer B, Budd GT, Hutchins L, Lower E, et al. Randomized phase III study of docetaxel compared with paclitaxel in metastatic breast cancer. J Clin Oncol 2005;23(24):5542-51.

20. Tannock IF, de Wit R, Berry WR, Horti J, Pluzanska A, Chi KN, et al. Docetaxel plus prednisone or mitoxantrone plus prednisone for advanced prostate cancer. $\mathrm{N}$ Engl $\mathrm{J}$ Med 2004;351(15):1502-12.

21. Van Cutsem E, Moiseyenko VM, Tjulandin S, Majlis A, Constenla M, Boni C, et al. Phase III study of docetaxel and cisplatin plus fluorouracil compared with cisplatin and fluorouracil as first-line therapy for advanced gastric cancer: a report of the V325 Study Group. J Clin Oncol 2006;24(31):4991-7.

22. Edelman MJ. Novel taxane formulations and microtubule-binding agents in non-small-cell lung cancer. Clin Lung Cancer 2009;10 Suppl 1:S30-4.

23. Nettles JH, Li H, Cornett B, Krahn JM, Snyder JP, Downing KH. The binding mode of epothilone A on alpha,beta-tubulin by electron crystallography. Science 2004;305(5685):866-9.

24. Altmann KH, Gertsch J. Anticancer drugs from nature--natural products as a unique source of new microtubule-stabilizing agents. Nat Prod Rep 2007;24(2):327-57.

25. Altmann KH, Pfeiffer B, Arseniyadis S, Pratt BA, Nicolaou KC. The Chemistry and Biology of Epothilones-The Wheel Keeps Turning. ChemMedChem 2007;2(4):396-423.

26. Altmann KH, Wartmann M, O'Reilly T. Epothilones and related structures--a new class of microtubule inhibitors with potent in vivo antitumor activity. Biochim Biophys Acta 2000;1470(3):M79-91.

27. Gradishar W. Management of advanced breast cancer with the epothilone B analog, ixabepilone. Drug Des Devel Ther 2009;3:163-71.

28. Dumontet C, Jordan MA. Microtubule-binding agents: a dynamic field of cancer therapeutics. Nat Rev Drug Discov;9(10):790-803.

29. Freedman RA, Bullitt E, Sun L, Gelman R, Harris G, Ligibel JA, et al. A Phase II Study of Sagopilone (ZK 219477; ZK-EPO) in Patients With Breast Cancer and Brain Metastases. Clin Breast Cancer.

30. Rustin G, Reed N, Jayson GC, Ledermann JA, Adams M, Perren T, et al. A phase II trial evaluating two schedules of sagopilone (ZK-EPO), a novel epothilone, in patients with platinum-resistant ovarian cancer. Ann Oncol.

31. Stupp R, Tosoni A, Bromberg JE, Hau P, Campone M, Gijtenbeek J, et al. Sagopilone (ZKEPO, ZK 219477) for recurrent glioblastoma. A phase II multicenter trial by the European Organisation for Research and Treatment of Cancer (EORTC) Brain Tumor Group. Ann Oncol.

32. Steel GG. Terminology in the description of drug-radiation interactions. Int $\mathbf{J}$ Radiat Oncol Biol Phys 1979;5(8):1145-50.

33. Steel GG, Peckham MJ. Exploitable mechanisms in combined radiotherapy-chemotherapy: the concept of additivity. Int J Radiat Oncol Biol Phys 1979;5(1):85-91. 
34. Bentzen SM, Harari PM, Bernier J. Exploitable mechanisms for combining drugs with radiation: concepts, achievements and future directions. Nat Clin Pract Oncol 2007;4(3):172-80.

35. Milas L, Milas MM, Mason KA. Combination of taxanes with radiation: preclinical studies. Semin Radiat Oncol 1999;9(2 Suppl 1):12-26.

36. Milross CG, Mason KA, Hunter NR, Chung WK, Peters LJ, Milas L. Relationship of mitotic arrest and apoptosis to antitumor effect of paclitaxel. J Natl Cancer Inst 1996;88(18):1308-14.

37. Milross CG, Mason KA, Hunter NR, Terry NH, Patel N, Harada S, et al. Enhanced radioresponse of paclitaxel-sensitive and -resistant tumours in vivo. Eur $\mathrm{J}$ Cancer 1997;33(8):1299-308.

38. Sinclair WK, Morton RA. X-ray sensitivity during the cell generation cycle of cultured Chinese hamster cells. Radiat Res 1966;29(3):450-74.

39. Terasima T, Tolmach LJ. Variations in several responses of HeLa cells to x-irradiation during the division cycle. Biophys J 1963;3:11-33.

40. Pawlik TM, Keyomarsi K. Role of cell cycle in mediating sensitivity to radiotherapy. Int J Radiat Oncol Biol Phys 2004;59(4):928-42.

41. Geard CR, Jones JM, Schiff PB. Taxol and radiation. J Natl Cancer Inst Monogr 1993(15):89-94.

42. Kim JS, Amorino GP, Pyo H, Cao Q, Price JO, Choy H. The novel taxane analogs, BMS184476 and BMS-188797, potentiate the effects of radiation therapy in vitro and in vivo against human lung cancer cells. Int J Radiat Oncol Biol Phys 2001;51(2):525-34.

43. Liebmann J, Cook JA, Fisher J, Teague D, Mitchell JB. In vitro studies of Taxol as a radiation sensitizer in human tumor cells. J Natl Cancer Inst 1994;86(6):441-6.

44. Lobrich M, Jeggo PA. The impact of a negligent G2/M checkpoint on genomic instability and cancer induction. Nat Rev Cancer 2007;7(11):861-9.

45. Steren A, Sevin BU, Perras J, Angioli R, Nguyen H, Guerra L, et al. Taxol sensitizes human ovarian cancer cells to radiation. Gynecol Oncol 1993;48(2):252-8.

46. Baumgart T, Klautke G, Kriesen S, Kuznetsov SA, Weiss DG, Fietkau R, et al. Radiosensitizing effect of epothilone B on human epithelial cancer cells. Strahlenther Onkol 2012;188(2):177-84.

47. Gupta N, Hu LJ, Deen DF. Cytotoxicity and cell-cycle effects of paclitaxel when used as a single agent and in combination with ionizing radiation. Int $\mathrm{J}$ Radiat Oncol Biol Phys 1997;37(4):885-95.

48. Leonard CE, Chan DC, Chou TC, Kumar R, Bunn PA. Paclitaxel enhances in vitro radiosensitivity of squamous carcinoma cell lines of the head and neck. Cancer Res 1996;56(22):5198-204.

49. Liebmann J, Cook JA, Fisher J, Teague D, Mitchell JB. Changes in radiation survival curve parameters in human tumor and rodent cells exposed to paclitaxel (Taxol). Int $\mathrm{J}$ Radiat Oncol Biol Phys 1994;29(3):559-64.

50. Tishler RB, Geard CR, Hall EJ, Schiff PB. Taxol sensitizes human astrocytoma cells to radiation. Cancer Res 1992;52(12):3495-7.

51. Zanelli GD, Quaia M, Robieux I, Bujor L, Santarosa M, Favaro D, et al. Paclitaxel as a radiosensitiser: a proposed schedule of administration based on in vitro data and pharmacokinetic calculations. Eur J Cancer 1997;33(3):486-92.

52. Mason KA, Hunter NR, Milas M, Abbruzzese JL, Milas L. Docetaxel enhances tumor radioresponse in vivo. Clin Cancer Res 1997;3(12 Pt 1):2431-8. 
53. Mason KA, Milas L, Peters LJ. Effect of paclitaxel (taxol) alone and in combination with radiation on the gastrointestinal mucosa. Int J Radiat Oncol Biol Phys 1995;32(5):1381-9.

54. Milas L, Saito Y, Hunter N, Milross CG, Mason KA. Therapeutic potential of paclitaxelradiation treatment of a murine ovarian carcinoma. Radiother Oncol 1996;40(2):163-70.

55. Hofstetter B, Vuong V, Broggini-Tenzer A, Bodis S, Ciernik IF, Fabbro D, et al. Patupilone acts as radiosensitizing agent in multidrug-resistant cancer cells in vitro and in vivo. Clin Cancer Res 2005;11(4):1588-96.

56. Hennequin C, Giocanti N, Favaudon V. S-phase specificity of cell killing by docetaxel (Taxotere) in synchronised HeLa cells. Br J Cancer 1995;71(6):1194-8.

57. Hennequin C, Giocanti N, Favaudon V. Interaction of ionizing radiation with paclitaxel (Taxol) and docetaxel (Taxotere) in HeLa and SQ20B cells. Cancer Res 1996;56(8):1842-50.

58. Milas L, Hunter NR, Mason KA, Kurdoglu B, Peters LJ. Enhancement of tumor radioresponse of a murine mammary carcinoma by paclitaxel. Cancer Res 1994;54(13):3506-10.

59. Milas L, Hunter NR, Mason KA, Milross CG, Saito Y, Peters LJ. Role of reoxygenation in induction of enhancement of tumor radioresponse by paclitaxel. Cancer Res 1995;55(16):35648.

60. Garcia-Barros M, Paris F, Cordon-Cardo C, Lyden D, Rafii S, Haimovitz-Friedman A, et al. Tumor response to radiotherapy regulated by endothelial cell apoptosis. Science 2003;300(5622):1155-9.

61. Honore S, Pasquier E, Braguer D. Understanding microtubule dynamics for improved cancer therapy. Cell Mol Life Sci 2005;62(24):3039-56.

62. Bley CR, Jochum W, Orlowski K, Furmanova P, Vuong V, McSheehy PM, et al. Role of the microenvironment for radiosensitization by patupilone. Clin Cancer Res 2009;15(4):133542.

63. Escuin D, Kline ER, Giannakakou P. Both microtubule-stabilizing and microtubuledestabilizing drugs inhibit hypoxia-inducible factor-1alpha accumulation and activity by disrupting microtubule function. Cancer Res 2005;65(19):9021-8.

64. Bocci G, Nicolaou KC, Kerbel RS. Protracted low-dose effects on human endothelial cell proliferation and survival in vitro reveal a selective antiangiogenic window for various chemotherapeutic drugs. Cancer Res 2002;62(23):6938-43.

65. Stalder MW, Anthony CT, Woltering EA. Metronomic dosing enhances the anti-angiogenic effect of epothilone B. J Surg Res;169(2):247-56.

66. Pasquier E, Carre M, Pourroy B, Camoin L, Rebai O, Briand C, et al. Antiangiogenic activity of paclitaxel is associated with its cytostatic effect, mediated by the initiation but not completion of a mitochondrial apoptotic signaling pathway. Mol Cancer Ther 2004;3(10):130110.

67. Ferretti S, Allegrini PR, O'Reilly T, Schnell C, Stumm M, Wartmann M, et al. Patupilone induced vascular disruption in orthotopic rodent tumor models detected by magnetic resonance imaging and interstitial fluid pressure. Clin Cancer Res 2005;11(21):7773-84.

68. Jain RK. Normalization of tumor vasculature: an emerging concept in antiangiogenic therapy. Science 2005;307(5706):58-62.

69. Carmeliet P, Jain RK. Principles and mechanisms of vessel normalization for cancer and other angiogenic diseases. Nat Rev Drug Discov;10(6):417-27.

70. Lau DH, Xue L, Young LJ, Burke PA, Cheung AT. Paclitaxel (Taxol): an inhibitor of angiogenesis in a highly vascularized transgenic breast cancer. Cancer Biother Radiopharm 1999;14(1):31-6. 
71. Rohrer Bley C, Orlowski K, Furmanova P, McSheehy PM, Pruschy M. Regulation of VEGF-expression by patupilone and ionizing radiation in lung adenocarcinoma cells. Lung Cancer 2011;73(3):294-301.

72. Borghaei RC, Gorski G, Javadi M. NF-kappaB and ZBP-89 regulate MMP-3 expression via a polymorphic site in the promoter. Biochem Biophys Res Commun 2009;382(2):269-73.

73. Agemy L, Harmelin A, Waks T, Leibovitch I, Rabin T, Pfeffer MR, et al. Irradiation enhances the metastatic potential of prostatic small cell carcinoma xenografts. Prostate 2008;68(5):530-9.

74. Camphausen K, Moses MA, Beecken WD, Khan MK, Folkman J, O'Reilly MS. Radiation therapy to a primary tumor accelerates metastatic growth in mice. Cancer Res 2001;61(5):220711.

75. Jadhav U, Mohanam S. Response of neuroblastoma cells to ionizing radiation: modulation of in vitro invasiveness and angiogenesis of human microvascular endothelial cells. Int $\mathrm{J}$ Oncol 2006;29(6):1525-31.

76. Qian LW, Mizumoto K, Urashima T, Nagai E, Maehara N, Sato N, et al. Radiation-induced increase in invasive potential of human pancreatic cancer cells and its blockade by a matrix metalloproteinase inhibitor, CGS27023. Clin Cancer Res 2002;8(4):1223-7.

77. Speake WJ, Dean RA, Kumar A, Morris TM, Scholefield JH, Watson SA. Radiation induced MMP expression from rectal cancer is short lived but contributes to in vitro invasion. Eur J Surg Oncol 2005;31(8):869-74.

78. Cheng JC, Chou CH, Kuo ML, Hsieh CY. Radiation-enhanced hepatocellular carcinoma cell invasion with MMP-9 expression through PI3K/Akt/NF-kappaB signal transduction pathway. Oncogene 2006;25(53):7009-18.

79. Park CM, Park MJ, Kwak HJ, Lee HC, Kim MS, Lee SH, et al. Ionizing radiation enhances matrix metalloproteinase-2 secretion and invasion of glioma cells through Src/epidermal growth factor receptor-mediated p38/Akt and phosphatidylinositol 3-kinase/Akt signaling pathways. Cancer Res 2006;66(17):8511-9.

80. Strup-Perrot C, Vozenin-Brotons MC, Vandamme M, Linard C, Mathe D. Expression of matrix metalloproteinases and tissue inhibitor metalloproteinases increases in X-irradiated rat ileum despite the disappearance of CD8a T cells. World J Gastroenterol 2005;11(40):6312-21.

81. Susskind H, Hymowitz MH, Lau YH, Atkins HL, Hurewitz AN, Valentine ES, et al. Increased plasma levels of matrix metalloproteinase- 9 and tissue inhibitor of metalloproteinase1 in lung and breast cancer are altered during chest radiotherapy. Int J Radiat Oncol Biol Phys 2003;56(4):1161-9.

82. Remacle AG, Rozanov DV, Baciu PC, Chekanov AV, Golubkov VS, Strongin AY. The transmembrane domain is essential for the microtubular trafficking of membrane type-1 matrix metalloproteinase (MT1-MMP). J Cell Sci 2005;118(Pt 21):4975-84.

83. Sbai O, Ferhat L, Bernard A, Gueye Y, Ould-Yahoui A, Thiolloy S, et al. Vesicular trafficking and secretion of matrix metalloproteinases-2, -9 and tissue inhibitor of metalloproteinases-1 in neuronal cells. Mol Cell Neurosci 2008;39(4):549-68.

84. Schnaeker EM, Ossig R, Ludwig T, Dreier R, Oberleithner H, Wilhelmi M, et al. Microtubule-dependent matrix metalloproteinase-2/matrix metalloproteinase-9 exocytosis: prerequisite in human melanoma cell invasion. Cancer Res 2004;64:8924-31.

85. Stearns ME, Wang M. Taxol blocks processes essential for prostate tumor cell (PC-3 ML) invasion and metastases. Cancer Res 1992;52(13):3776-81.

86. Bijman MN, van Nieuw Amerongen GP, Laurens N, van Hinsbergh VW, Boven E. Microtubule-targeting agents inhibit angiogenesis at subtoxic concentrations, a process 
associated with inhibition of Rac1 and Cdc42 activity and changes in the endothelial cytoskeleton. Mol Cancer Ther 2006;5(9):2348-57.

87. Hu YL, Li S, Miao H, Tsou TC, del Pozo MA, Chien S. Roles of microtubule dynamics and small GTPase Rac in endothelial cell migration and lamellipodium formation under flow. J Vasc Res 2002;39(6):465-76.

88. Wiskirchen J, Schober W, Schart N, Kehlbach R, Wersebe A, Tepe G, et al. The effects of paclitaxel on the three phases of restenosis: smooth muscle cell proliferation, migration, and matrix formation: an in vitro study. Invest Radiol 2004;39(9):565-71.

89. Ogasawara M, Matsubara T, Suzuki H. Screening of natural compounds for inhibitory activity on colon cancer cell migration. Biol Pharm Bull 2001;24(6):720-3.

90. Westerlund A, Hujanen E, Hoyhtya M, Puistola U, Turpeenniemi-Hujanen T. Ovarian cancer cell invasion is inhibited by paclitaxel. Clin Exp Metastasis 1997;15(3):318-28.

91. Jiang H, Tao W, Zhang M, Pan S, Kanwar JR, Sun X. Low-dose metronomic paclitaxel chemotherapy suppresses breast tumors and metastases in mice. Cancer Invest 2010;28(1):7484 .

92. O'Reilly T, Wartmann M, Brueggen J, Allegrini PR, Floersheimer A, Maira M, et al. Pharmacokinetic profile of the microtubule stabilizer patupilone in tumor-bearing rodents and comparison of anti-cancer activity with other MTS in vitro and in vivo. Cancer Chemother Pharmacol 2008;62(6):1045-54.

93. Strube A, Hoffmann J, Stepina E, Hauff P, Klar U, Kakonen SM. Sagopilone inhibits breast cancer bone metastasis and bone destruction due to simultaneous inhibition of both tumor growth and bone resorption. Clin Cancer Res 2009;15(11):3751-9.

94. Zhang AL, Russell PJ. Paclitaxel suppresses the growth of primary prostate tumours (RM1) and metastases in the lung in C57BL/6 mice. Cancer Lett 2006;233(1):185-91.

95. Furmanova P, Eggel M, Millard A, Pruschy M. The Microtubule Stabilizer Patupilone Counteracts Ionizing Radiation-Induced Matrix Metalloproteinase Activity and Tumor Cell Invasion. Manuscript submitted. 